\title{
Особенности предселекции в работе с интрогрессивными аллоплазматическими ДГ-линиями мягкой пшеницы
}

Першина Л.А. ${ }^{1 *}$, ә.б.н., г.н.с.; Трубачеева Н.В. ${ }^{1}$, к.б.н., н.с.; Белан И.А. ${ }^{2}$, к.с.х.н., зав. лаб.; Россеева Л.П. ${ }^{2}$, к.с.-х.н., в.н.с.

${ }^{1}$ ИЦиГ СО РАН, Новосибирск, Россия;

${ }^{2}$ ФГБНУ «Омский ФНЦ», Омск, Россия.

*e-mail:pershina@bionet.nsc.ru

В работе с аллоплазматическими интрогрессивными ДГ-линиями, которые планируется включать в селекционный процесс, показана необходимость их предселекиионного изучения. На этом этапе необходим отбор ииитогенетически стабильных 42-хромосомных ДГ-линий с высоким уровнем фертильности, молекулярный анализ для подтверждения наличия иеелевых генов и сохранения стабильности ядерно-циитоплазматических взаимодействий. Кроме того, важен учет и запланированное использование генетически идентичных ДГ-линий, сформированных из андрогенных растений, развившихся в составе кластеров (семейств).

Ключевые слова: ДГ-линии, аллоплазматические линии, предселекция, пшеница.

\section{Features of pre-breeding in work with alloplasmic introgression DH-lines of bread wheat}

Pershina Lidiya Aleksandrovna ${ }^{I}$, Trubacheeva Natalia Victorovna ${ }^{I}$, Belan Igor Aleksandrovich ${ }^{2}$, Rosseva Ludmila Petrovna ${ }^{2}$.

${ }^{1}$ Institute of Cytology and Genetics SB RAS, Novosibirsk, Russia

${ }^{2}$ Siberian Research Institute of Agriculture, Russian Academy of Agricultural Sciences, Omsk, Russia

In work with alloplasmic introgression DH lines, which are planned to be included in the breeding, the need for their pre-breeding study is shown. At this stage, it is necessary to select cytogenetically stable 42-chromosomal DH lines with a high level of fertility, molecular analysis to confirm the presence of target genes and maintain the stability of nuclear-cytoplasmic interactions. In addition, the accounting and planned use of genetically identical DH lines formed from androgenic plants that have developed as part of clusters (families) is important.

Key words: DH-lines, alloplasmic lines, pre-breeding, wheat.

Технологии получения удвоенных гаплоидных (ДГ) линий широко используются при выполнении генетических исследований и в селекции многих культурных растений. ДГ-линии создаются в течение одного года. 
Такие линии являются гомозиготными и могут быть быстро проанализированы в повторных испытаниях. Это значительно ускоряет отбор генотипов с желаемыми признаками в процессе развития растений, особенно в сочетании с использованием молекулярных маркеров [1].

Ранее в наших работах была показана возможность и целесообразность включения интрогрессивных ДГ-линий мягкой пшеницы, полученных на основе аллоплазматических линий (H. vulgare)-T. aestivum, в качестве исходного материала в селекционный процесс при создании новых сортов яровой мягкой пшеницы [2]. Аллоплазматические линии - это генотипы, сочетающие ядерный геном одного вида, а цитоплазму другого. Их образование происходит в результате повторяющихся возвратных скрещиваний отдаленных гибридов с отцовским видом [3]. При замещении цитоплазмы нарушаются взаимодействия между ядром и органельными геномами, что обуславливает новые ядерно-цитоплазматические взаимодействия, которые могут вызвать эпигенетические модификации ядерных генов [4]. В связи с этим аллоплазматические линии с восстановленной фертильностью рассматривают в качестве дополнительного источника биоразнообразия культурных растений [5].

ДГ-линии на основе интрогрессивных аллоплазматических линий $(H$. vulgare)-T. aestivum в наших работах получали с использованием метода культивирования пыльников [6]. Источниками для формирования ДГ-линий служили андрогенные растения со спонтанно удвоенным числом хромосом $(2 \mathrm{n}=42)$ и проявившие фертильность. В зависимости от генотипов частота развития растений с удвоенным числом хромосом наблюдалась от 18 до 45 $\%$. Установлено, что эффективность использования андрогенных растений для формирования ДГ-линий в работе с аллоплазматическими интрогрессивными генотипами, развившимися в культуре пыльников, может быть связана со следующими ограничениями: образованием большого числа нежизнеспособных хлорофилл-дефектных проростков; развитием анеуплоидов среди зеленых проростков; утратой целевых генов; формированием кластеров генетически идентичных проростков. В связи с этим включению ДГ-линий в селекционный процесс должен предшествовать комплекс предселекционного изучения. В нашей работе предусмотрено формирование каждой ДГ-линии из семян одного колоса, независимо от того, было это одиночное растение, или кластер растений. При первичном размножении ДГ-линий в теплице оценивается уровень цитогенетической стабильности; уровень фертильности; выполняется молекулярный анализ с целью выявления генов устойчивости к грибным патогенам, интрогрессированных в геном растений, использованных в качестве доноров пыльников; на основе результатов анализа состояния маркерных последовательностей митохондриальной и хлоропластной ДНК определяется уровень стабильности ядерно-цитоплазматиче- 
ской совместимости; по проявлению фенотипических признаков и результатам структурного анализа оцениваются ДГ-линии, сформированные из семян сестринских андрогенных растений, развившихся потенциально в одних семействах. В летний период в условиях Новосибирска на поле или изолированных участках на естественном фоне оценивается устойчивость к листостебельным патогенам; устойчивость к полеганию; уровень фертильности. В результате отбора ДГ-линий, как сформированных от единичных андрогенных растений, так и от растений, развившихся в семействах, выявляются наиболее перспективные для селекции.

Выделены аллоплазматические интрогрессивные ДГ-линии, которые характеризуются высокой сортообразующей способностью. В результате их гибридизации как между собой, так и с перспективными линиями, выделенными из коммерческих сортов, получено многообразие гибридных форм, включенных в селекционный процесс. Разрабатывается стратегия оптимального использования в селекции сестринских ДГ-линий, характеризующихся высокой продуктивностью, качеством зерна и устойчивостью к биотическим факторам.

Благодарности: Основные разделы работы выполнены при поддержке РФФИ (проект № 20-016-00196).

\section{Список литературы}

1. Germana M.A. Gametic embryogenesis and haploid technology as valuable support to plant breeding / M.A. Germana // Plant Cell Rep. -2011 . - P. 839-857.

2. Першина Л.А. Аллоплазматические рекомбинантные линии (H. vulgare)T. Aestivum с транслокацией 1RS.1BL: исходные генотипы для создания сортов мягкой пшеницы / Л.А.Першина, Л.И. Белова, Н.В.Трубачеева, Т.С. Осадчая, В.К. Шумный, И.А. Белан, Л.П. Россеева, В.В. Немченко, С.Н. Абакумов // Вавиловский журнал генетики и селекции, 2018. - С.544-552.

3. Tsunewaki K. Plasmon analysis as the counterpart of genome analysis $/ \mathrm{K}$. Tsunewaki// Methods of genome analysis in plant - Ed. Jauhar P.P. Boca Raton, New York, London, Tokyo: CRC Press, 1996. - P. 271-299.

4. Noyszewski A.K, Ghavami F., Alnemer L.M., Soltani A., Gu Y.Q., Huo N., Meinhardt S., Kianian P.M., Kianian S.F. Accelerated evolution of the mitochondrial genome in an alloplasmic line of durum wheat /A.K. Noyszewski, F. Ghavami, L.M. Alnemer, A. Soltani, Y.Q.Gu, N. Huo, S. Meinhardt, P.M.Kianian, S.F. Kianian // BMC genomics 2014. - P.1-16.

5. Liu C.G., Wu Y. W., Hou H., Zhang C., Zhang Y., McIntosh R.A. Value and utilization of alloplasmic common wheats with Aegilops crassa cytoplasm / C.G. Liu, Y.W. Wu., H. Hou, C. Zhang, Y. Zhang, R.A.McIntosh // Plant Breeding - 2008. - P. 407-410.

6. Осадчая Т.С., Першина Л.А., Трубачеева Н.В., Белан И.А, Россеева Л.П., Девяткина Э.П. Способность к андрогенезу эуплазматических линий мягкой пшеницы и аллоплазматических рекомбинантных линий (H. vulgare)-T. aestivum с транслокациями 1RS.1BL и 7DL-7Ai и получение дигаплоидных линий / Т.С. Осадчая, Л.А. Першина, Н.В. Трубачеева, И.А. Белан, Л.П. Россеева, Э.П. Девяткина // Вавиловский журнал генетики и селекции - 2014. - С. 650-659. 